\title{
A Critical Framework to Develop Human-Centric Positive Energy Districts: Towards Justice, Inclusion, and Well-Being
}

\author{
Minh-Thu Nguyen* and Susana Batel \\ Instituto Universitário de Lisboa (ISCTE-IUL), Cis-IUL, Lisbon, Portugal
}

Positive Energy Districts (PEDs) are a new energy initiative from European member states. They are, simply put, local districts which produce more energy than they consume. PEDs are expected to adopt a more human-centric perspective in order to create more liveable and sustainable urban neighbourhoods. However, as previous research on energy transitions has demonstrated, the mainstream approach and technocratic tradition of research and policy vis-à-vis energy transitions could result in the perpetuation of social inequalities, energy injustices, and the passive participation of citizens also within PEDs.

OPEN ACCESS

Edited by: Matthias Haase, SINTEF, Norway

Reviewed by:

Emma Elizabeth Heffernan, University of Wollongong, Australia

Sujit Sikder,

Leibniz Institute for Ecological Urban and Regional Development (IOER), Germany

*Correspondence: Minh-Thu Nguyen mtnnu@iscte-iul.pt

Specialty section

This article was submitted to Urban Energy End-Use,

a section of the journal

Frontiers in Sustainable Cities

Received: 05 April 2021 Accepted: 28 July 2021 Published: 31 August 2021

Citation:

Nguyen M-T and Batel S (2021) A

Critical Framework to Develop

Human-Centric Positive Energy Districts: Towards Justice, Inclusion, and Well-Being

Front. Sustain. Cities 3:691236. doi: 10.3389/frsc.2021.691236
Hence, it is crucial in these early days of PEDs to discuss what a human-centric approach should entail and how it should be enacted. Based on a narrative literature review of critical social sciences' energy research (and specifically from social and environmental psychology), this paper will propose a critical framework containing five key dimensions which are relevant for creating more just and inclusive PEDs. These are: uncertainty, risk perception and trust; distributive justice; recognition justice and people-place relations; procedural justice; and, routines, capabilities and lived experiences. To that end, it will also discuss the different implications of mainstream and critical approaches in energy research and social sciences in relation to the deployment of human-centric PEDs. The review concludes that in order to successfully deploy human-centric PEDs, a critical approach is needed and presents some concrete recommendations for future research and policy in order to adopt such an approach. These include: considering justice, inclusion and the well-being of affected socio-ecological systems in the whole-life cycle of PEDs; better integration of indigenous capabilities; and, an ethos of de-growth and circularity in their deployment.

Keywords: human-centric perspective, postivie energy districts, social psychology, environmental psychology, critical approach, interdisciplinarity

\section{INTRODUCTION}

\section{Positive Energy Districts Within a Human-Centric Perspective: What Does It Mean?}

The transition to low-carbon energy sources has been a key focus amongst efforts to mitigate climate change in European countries (EU-27). Therein, the energy sector accounts for $78 \%$ of green-house gas (GHG) emissions from fossil-fuel sources in 2018, including from transportation (Eurostat, 2020). Bound by the Paris Agreement target of reducing 40\% of GHG emissions by 
2030, the EU 2030 climate and energy framework has committed to producing (or sourcing) more renewable energy forms. Furthermore, it intends to make energy distribution more efficient, and thus pro-actively encourages energy saving behaviours from end-consumers (European Commission, 2018).

To achieve this target, the EU and its member states have been building large scale renewable energy projects both within and outside Europe (e.g., wind farms in Mexico exploited by international energy utility companies, VelascoHerrejon and Bauwens, 2020). This has been accompanied by high voltage transmission and distribution grids whilst simultaneously controlling the energy demands of consumers via energy efficiency, market rules, and flexible prices (European Commission, 2019). The energy centralisation model of the previous fossil-fuel and nuclear based system is argued to be incompatible with intermittent sources of renewable energy. Moreover, the perpetuation of top-down decision-making, which is often met with local opposition, is also problematic (Wolsink, 2020). Hence, many European countries are developing digital technology and infrastructure which enables local renewable energy production and exchange. This reduces dependence upon the central grid, whilst aiming to also empower citizens and stakeholders to join the state in governing their energy system. This is especially the case in smart and/or sustainable cities (Caramizaru and Uihlein, 2020; Levenda et al., 2020).

Positive Energy Districts and Neighbourhoods (PEDs) represent one such decentralised energy initiative. The program aims to facilitate the design, implementation and scaling-up of 100 districts across Europe which produce more renewable energy than they consume by 2025. Established in 2018 by the Action 3.2 on Smart Cities and Communities of the European Strategic Energy Technology (SET) Plan, the PEDs program framework was co-created by city representatives, research and innovation representatives, and urban stakeholders via workshops and working groups organised by the Joint Programming Initiative (JPI) Urban Europe in 2019. Within the PEDs framework, the three main functions of energy production, energy efficiency and energy flexibility are leveraged are leveraged in order to achieve climate neutrality and energy surplus (JPI Urban Europe/SET Plan Action 3.2, 2020a). This means that in order to meet zero emission targets, PEDs require local renewable energy production at municipal and household scales for selfconsumption and feeding to the grid. This surplus of electricity could then be utilised to power district heating and/or cooling, but also electrical vehicle charging. On the demand side, energy efficiency measures such as retrofitting buildings, smart-meters, and public or shared transportation are implemented in order to reduce energy consumption. With smart-grids, energy storage, and ICT technologies, the energy flexibility function is set to optimise energy systems by shifting the load in peak hours and thereby exchange the energy surplus (see Sikder et al., 2016, for an example of optimised energy systems and the actors involved at the neighbourhood scale).

In addition to this, "human-centric" is one of the key guiding principles used by PEDs to ensure the quality of life of cities and citizens, including preventing energy poverty as well as promoting sustainability and resilience of energy supply (JPI
Urban Europe/SET Plan Action 3.2, 2020b, p. 8). However, within this PEDs framework, no specific nor concrete definitions of what that means exactly, and recommendations on how to implement it, are identified. Rather, this is left to local authorities and other stakeholders to interpret what those human-centric principles should signify and imply. In turn, a recent review by Ingeborgrud et al. (2020) highlights that energy and urban policy makers are still routinely in favour of top-down and centralised economic and technological interventions to address energy problems. This mainstream approach normally only accounts for the human dimensions of energy decision-making in a very superficial, cost-benefit and normative way. Taking social and psychological aspects into account in an in-depth, contextual and political way is often overlooked. Alternatively, social sciences' critical approaches which focus upon the promotion of the wellbeing of people and ecological systems alike, are able to consider and also address social inequalities and related injustices in a transformative manner. In fact, recent research on smart cities and associated policies and initiatives towards decentralisation and sustainability, has been demonstrating how these are still often performed within business-as-usual, neoliberal capitalist, rationales, and associated green growth logics (Levenda et al., 2020). The implications of perpetuating this type of rationale, namely in terms of the reproduction of social inequalities and environmental destruction, have been increasingly pointed out by the so-called critical turn in social sciences and humanities (SSH) energy research (see Batel, 2020; Silva and Sareen, 2021). Such an approach can then give useful insights to develop a critical framework on what should be human-centric PEDs, what this should mean, and how it should be materialised.

\section{The Need for Critical SSH Energy Research for PEDs}

A critical SSH approach can be described as recognising that people-expert-place-technology relations are socially coconstructed throughout time and space (Walker et al., 2011). However, it can also show that they reflect and often reproduce certain power asymmetries and related inequalities and injustices (Levenda et al., 2021). In other words, this critical approach contests the idea that science and research are value-free and apolitical. Instead, it aims to unveil, both in research, policymaking, planning and practise, how groups and individuals advance and promote certain interests and privileges instead of others, who benefits from this, and with what consequences (Batel, 2020). A relevant example of the type of questions that an SSH critical approach asks, examines and addresses in the context of PEDs could be: to what extent does the way PEDs are being developed and implemented promote or else explicitly avoid environmental gentrification? The latter is "characterised by the implementation of environmental or sustainability initiatives that leads to the exclusion, marginalisation and displacement of economically marginalised residents" (Pearsall and Anguelovski, 2016, p. 2).

The main aim of this paper is two-fold. Firstly, it argues for (and demonstrates) the relevance of adopting a critical SSH framework-in opposition to a mainstream SSH approach-for 
supporting the implementation of human-centric PEDs. Such PEDs are just, inclusive and promote people's and ecological systems' well-being, and enable design of related research, planning and policy agendas. Secondly, it proposes and describes a critical SSH framework by systematising its key dimensions based on a narrative literature review.

$\mathrm{SSH}$ research on energy transitions and sustainability and, particularly, contributions from critical social and environmental psychology, can offer many useful insights and lessons for PEDs. These enable researchers and planners to reflect upon what a human-centric approach should entail in order to safeguard "real" justice and sustainability in their transformational implementation. Firstly, this research has demonstrated that the siting of renewable energy infrastructures often also gives rise to socio-ecological injustices. This transpires when the political, economic, environmental, psycho-social and health impacts of those infrastructures and related technologies are not recognised, considered nor distributed equally (Jenkins et al., 2016; Batel and Devine-Wright, 2017). Secondly, this specific body of research has highlighted how energy poverty and related wellbeing have become an alarming issue across European countries, given that private energy services and low-carbon technologies' companies tend to discriminate against customers who generate less profit (or, are less capable of investing in and adapting to new technologies). Hence, such customers are excluded from affordable, efficient and quality low-carbon innovations (Sovacool et al., 2019a). Another key focus of this body of research has been on how energy-related policies and planning still often only incentivise a low and passive participation from citizens. This reflects traditional top-down and technocratic mainstream models of energy governance which fail to include, understand and address citizens' and communities' concerns from the beginning of energy-related projects, which often leads to opposition later on in their implementation phase (Carvalho et al., 2019; Levenda et al., 2020). At the same time, most citizens lack access to and engagement with technological innovations in their everyday lives-such as smart meters, photovoltaic panels and electric cars-due to socio-economic inequalities, lack of knowledge and other reasons. This has been shown to reduce active participation in energy issues (Ryghaug et al., 2018). Even when the impacts of energy are omnipresent, visible and invisible, in everyone's everyday life (Ambrose, 2020), the dominant consumerism focus of energy governance has been shown to alienate people from being political subjects-or energy citizens-in the public realm. Namely, to actually engage with have a voice, and be able to influence energy decision-making processes (Lennon et al., 2020; Levenda et al., 2020).

Hence, in this paper, we argue and propose that a critical human-centric perspective vis-à-vis PEDs needs to consider key socio-psychological aspects, namely the well-being of energy citizens, including the impacts of PEDs on their lived experiences, health and subjectivities. Moreover, socio-environmental justice and equity, in terms of inclusion, process and outcome must also be considered. To further clarify the relevance of considering these factors within a critical perspective for deploying humancentric PEDs, as opposed to considering them within a more mainstream, positivist perspective, we will also accentuate if and how these distinct approaches have been defined and considered, and the associated implications for human-centric PEDs.

\section{METHODOLOGY-NARRATIVE LITERATURE REVIEW OF CRITICAL SSH ENERGY RESEARCH}

Given that social science research on the human dimensions of PEDs and related smart city initiatives is still limited (see, for exceptions, Sadowski and Levenda, 2020; Levenda et al., 2021), an interdisciplinary narrative literature review of critical SSH energy research was conducted as a methodology. This was done in order to systematise the key dimensions to be considered within a critical framework for human-centric PEDs, and to gather insights from existing relevant studies in social science energy research (see Sovacool et al., 2018). This methodology also enabled an in-depth discussion of the implications of adopting a critical vs. a mainstream approach. Overall, this narrative literature review consisted of three main steps.

Firstly, the identification of key articles, books and other published research and essays which adopted and contributed to a critical approach to SSH energy research. This included underrepresented disciplines in social science energy research, such as from critical social and environmental psychology. Despite the latter's potential to contribute to more just and inclusive energy transitions (Di Masso, 2012; Batel et al., 2016; de Carvalho and Cornejo, 2018), it has often been left unexplored in this regard. The social and environmental psychology field has been contributing to understanding and explaining the human dimensions and psycho-social impacts of society-environment-technology interactions as well as studying how human dimensions could be integrated into the solution to problems emerging from those interactions (Clayton et al., 2016; Räthzel and Uzzell, 2019a). Hence, it can provide useful insights in understanding the significant processes and impacts associated with people's psychosocial relations with PEDs.

Critical approaches in social and environmental psychology highlight that "individuals are the sum of their social relations, i.e., they are the cause and consequence of their relations to others and the environment," including power relations which create and reproduce socio-environmental inequalities and injustices (Uzzell and Räthzel, 2009; Batel et al., 2016). In relation to creating sustainable societies, the research focus should change from the individual (the still current focus of more mainstream, positivist approaches) to "the relations of production and consumption and the social and political relations within which values, attitudes and behaviours are formed, and unsustainable ways of living and working as well as the environment are produced and reproduced" (Uzzell and Räthzel, 2009, p. 340, Räthzel and Uzzell, 2019a). This means that instead of only trying to understand and change individuals' behaviours towards more energy efficient practises, acceptance of renewable energy infrastructures, use of electric cars, and so on and so forth, critical research focus more on examining and contesting the way current social, economic and political relations that contribute to unsustainability and socio-ecological injustices are collectively 
formed and maintained (see also Groves et al., 2013; Räthzel and Uzzell, 2019b).

This first step included publications which had an applied focus on any social aspects of energy transitions and, at an epistemological and conceptual level, departed from critical perspectives or assumptions. More specifically, these perspectives recognised that people-environment-technology relations and related meanings are socially co-constructed throughout time and space. Furthermore, they included recognition of the political dimensions of meaning-making in general, including academic research and had an openness to interdisciplinary investigation. Many also included an acknowledgement of the global, cultural, local/community and psycho-social dimensions and impacts of energy transitions associated with these factors (see also Batel and Rudolph, 2021).

As a second step, those publications were then analysed with the aim of identifying the key and transversal factors therein identified and associated discussions. These were the factors identified as required for a critical human-centric approach to energy transitions, systems and issues. In turn, this also allowed us to systematise the critical framework proposed below.

Thirdly, definitions and examples of the five key transversal factors identified in the previous step were collected with a view to defining and applying them in a critical way in the context of PEDs. However, they were also used to provide a clear distinction in relation to defining and applying them within a mainstream approach. This step resulted in the subsections within the section Results-the Five Key Dimensions of a Critical Conceptual Framework for Human-Centric PEDs, and is summarised in Table 1.

\section{RESULTS-THE FIVE KEY DIMENSIONS OF A CRITICAL CONCEPTUAL FRAMEWORK FOR HUMAN-CENTRIC PEDS}

Based on the narrative literature review as described above (and the subsequent iterative process of identifying, defining, separating, combining and systematising key factors), these socio-psychological factors are grouped into five interconnected dimensions, here proposed as the critical conceptual framework for fostering human-centric PEDs. Those five dimensions are:

- Uncertainty, risk perception and trust;

- Distributive justice;

- Recognition justice and people-place relations;

- Procedural justice;

- Routines, capabilities and lived experiences.

The following sections will define, exemplify and discuss these key socio-psychological dimensions, their differential uptake by mainstream/critical approaches, and their relevance in the context of PEDs.

\section{Uncertainty, Risk Perception and Trust-Background in PEDs and General Definition}

According to the SET-Plan Action 3.2 (SET-Plan Working Group, 2018), energy production for building stock, transportation and other demands in PEDs needs to be generated from renewable sources to ensure a net zero $\mathrm{CO}_{2}$ emission target. To make this easier, energy service companies (ESCO) would research, develop and provide micro-generation technologies and smart meters for citizens to produce and consume their own energy individually (or collectively) as an energy prosumer. Previous studies on public attitudes towards new energy technologies, and the siting of energy facilities and similar facilities, have indicated that risk perception and trust are normally strongly associated with specific attitudes (Lima, 2006). Namely, the higher the risk perception and the lack of trust in the social actors involved in the related decision-making process, the more people tend to reject them.

The tradition and technocratic definition of risk perception concerns the individual's evaluation, emotions and beliefs towards a potential threat (Lima, 2006; Weber and Stern, 2011). Meanwhile, trust is found to shape how people perceive risk, which depends on whether the parties involved can be relied upon to handle the technology by having expertise and values which the public is expecting and/or identifies with (Greenberg, 2014). Hence, it is crucial to consider risk perception and trust when deploying human-centric PEDs.

\section{Mainstream Approach}

Thus far, traditional, normative approaches have tended to explain risk perception and trust as individual processes by simply reflecting the publics' lack of information and cognitive biases in perceptions (see Steg et al., 2015). This manner of approaching risk perception and trust, in turn, favours planning and policy interventions which attempt to quantify, calculate and estimate risks in order to provide more and better information. However, they likewise dismiss the emotional, experiential, values and cultural dimensions that shape risk perception and trust (Douglas and Wildavsky, 1983; Lima et al., 2005; Groves et al., 2013). Indeed, research has shown that independently of technical-expert assessments of risks and of health impacts for certain technologies, if they are perceived to exist by the public, they can nonetheless negatively affect people's health. For instance, the work of Lima (2004) showed that communities living near a waste incinerator reported increased anxiety, stress and sleep deprivation due to the perceived health risks. Another consequence of a mainstream approach to risk and uncertainty is the tension between citizens' and state responsibilities in mitigating these risks. This increases the personal sense of responsibility in order to reduce risk e.g., moving home and place of living. However, the accountability to manage the risks should lie with those who create and propose them (Bickerstaff et al., 2008; Rolfe, 2018).

\section{Critical Approach}

Critical approaches to risk perception and trust have focused instead on showing that reactions to environmental or technological risks are influenced by social meaning-making processes of risk representation. These are shaped by social, cultural and political contexts and relations (Joffe, 2003; Bickerstaff, 2004; Lima and Castro, 2005). For instance, traditional and social media communication are key agents in the amplification or attenuation of certain risks: this has also 
TABLE 1 | Summary of mainstream and critical approaches to relevant socio-psychological factors for human-centric PEDs.

\begin{tabular}{ll}
\hline Dimensions & $\begin{array}{l}\text { Related PEDs } \\
\text { configurations }\end{array}$ \\
\hline $\begin{array}{l}\text { Uncertainty, risk } \\
\text { perception, and trust }\end{array}$ & $\begin{array}{l}\text { New energy and mobility } \\
\text { technologies and facilities }\end{array}$
\end{tabular}

Mainstream approach

DEFINITION (D): Risk perception is the irrational, uninformed and biased reaction by the public/community to a new, unknown and uncertain technology. It is mediated by trust in the proponents of the technology. SHORTCOMINGS OF INTERVENTIONS (SI): Mainly managed by risk analysis and by providing technical information to citizens; often do not address more subjective and cultural concerns.

D: Distributive justice is the sense of equal costs and benefits distribution from the outcomes of an energy project.

SI: Mainly managed by economic cost-benefit analysis, financially fair redistribution, and monetary/ material compensations, without considering current political economies and more historical, cultural, and symbolic dimensions.

D: Recognition justice is the recognition and inclusion of different needs of under-represented groups and places.

SI: Mainly providing different financial packages to vulnerable socio-demographic groups to enhance their energy efficacy; providing green innovations to stigmatised locations to increase their market value, whilst marginalising those who cannot afford it (green gentrification).

D: Procedural justice ensures that energy decision-making respects due process and representation to increase public acceptance and minimise local opposition.

SI: Understanding local opposition as only NIMBY, leading to consensus making techniques to legitimise interventions and avoid opposition; a soft way of controlling people's responses to energy projects.

D: Routines are individual habits based on personal attitudes, values, beliefs, and norms.

SI: Changing energy inefficient routine behaviours by targeted communications and nudging to relevant socio-demographic groups, but which often result in short run, individual effects, and counter-productive outcomes (rebound effect).
Critical approaches

DEFINITION (D): Risk perception and trust are shaped by wider collective, social, economic and political processes as well as related, unequal power relations.

INTERVENTIONS (I): Considering how perceived risk affects people's subjective well-being and affects; considering how risks are socio-environmentally distributed; and, mitigating these effects by involving all affected and interested publics in defining risks in planning and decision-making processes, including the cultural, affective and symbolic dimensions of risks.

D: Distributive injustice is the abstraction and commodification of economic value from other symbolic, spiritual and cultural values of the affected site and community. Distributive injustice is also the unequal distribution of rights and responsibilities. I: Considering how symbolic and cultural dimensions shape present senses of fairness; considering distributive justice across time (from extraction to decommission) and space (from local to global) in order to avoid energy colonialism and related psychosocial impacts.

D: Recognition injustice is the social and political process of disrespect, insult and degradation which devalue some people and some places and communities in comparison to others.

I: Considering people-place relations; contesting structural gender mainstreaming and ethnic-racial inequalities which cause energy and transport poverty; recognising and valuing alternative feminist, de-colonial, intersectional and indigenous knowledge; avoiding place stigmatisation and physical and psychological displacement.

D: Procedural injustice often reflects power imbalances in public participation due to structural constraints (e.g., gender relations) and lay-expert relations.

I: Acknowledging public as not NIMBY, not homogenous and static, but indigenous, common-sense, and experiential; involving citizens and communities in co-creation processes from the beginning of any initiative; being aware of, and dismantling, lay-expert power relations in knowledge co-production.

D: Routines are shaped by structural and materia infrastructures, meanings and power relations. I: Acknowledging structural constraints for changing routines such as political-economic governance including: rhythm of life; working schedules; and, infrastructures. Moreover, contesting energy efficiency imperatives or consumerism as usual, and focusing on lived experiences and capabilities. been recently highlighted with the COVID-19 pandemic (Cori et al., 2020). However, risk representations and people's relations with uncertainty are also markedly shaped by social factors and power relations, such as by current neoliberal capitalist dynamics (Groves, 2015). This can deeply impact upon and menace people's values, emotions, attachments and related well-being since they have to deal with uncertainty every day and in every domain. This includes the climate crisis, job precariousness, and housing instability (Casanova et al., 2019). For example, a study concerning the public acceptance of smart meters in Portugal has shown that people represented smart meters as not only potentially involving health risks and financial risks, but also as a loss of control and privacy. These factors were highly associated with the lack of acceptance and use of smart meters (Guerreiro 
et al., 2015). Another example relating to the relevance of trust and due process in the perception of risks (and other impacts of energy infrastructures), is given by Rudolph et al. (2017). These authors demonstrated how the annoyance felt by local communities living near "the world's largest wind turbine test centre in Denmark" was increased by their lack of involvement in that decision. This indicated that "the emotional constitution of perceived annoyance may not only be grounded in the actual source of nuisance, but also entangled in related issues, in our case the perception of an unfair planning process, which for some has even made them question their democratic rights in Denmark" (p. 88). This points out to the need for citizen and community engagement in a substantial way: but moreover in a way which considers the emotional and experiential dimensions of people's risk perceptions and related trust issues. This must concern not only the planning phase of an energy project, but also the very stage of making a decision whether or not to deploy a given energy initiative, project, and/or policy.

Given this, several changes of approach must be made. Firstly, not reproducing the deficit model of the public (or the idea that the public only needs to be provided with technically relevant information in a sufficient and easy to understand way) (Rodhouse et al., 2021). Secondly, not focusing on the artificial and stereotypical distinction between subjective lay perceptions and objective expert knowledge about risks. Both of these latter approaches must be met with a critical turn to the social and political construction of risk which emphasises the "politics of uncertainty" that shape contemporary societies (Beck, 1992; Giddens, 1999). This perspective critically challenges the singular and homogenous definition of risk and uncertainty prevailingly put forward by techno-scientific and political experts (Scoones et al., 2020). It thus allows for open discussion about who wins and who loses when uncertainties and risks are proposed, negotiated and tamed by different stakeholders (Groves, 2015; Scoones and Stirling, 2020). In other words, it clearly reveals and examines how certain risks and harms are constructed in certain ways by specific groups, such as harmless smart meters as presented by energy companies in order to pre-empt potential resistance to their deployment by the public (Guerreiro et al., 2015). Another example is when the Dutch heat transition was presented to the public as "technical, complex, urgent, sensitive, and high-risk," which can lead vulnerable households to feel like they have less agency and active role to play in this collective decision-making process (Rodhouse et al., 2021, p. 10).

\section{Distributive Justice-Background in PEDs and General Definition}

Decentralisation is believed to distribute energy production and consumption infrastructures more evenly across regions. Thereby, it ensures access, shared burdens and benefits. However, this might not entirely be the case. To be self-sufficient and in order to ensure a secured supply of energy, PEDs' inhabitants will potentially use more solar photovoltaic (PV) for microgeneration, electric vehicles (EV) to reduce emissions, and batteries to store any energy surplus. Furthermore, distribution system operators (DSO) would develop smart grids to shift the load in peak hours and/or exchange energy supply with other regions outside of the PED's geographical boundary, as in the case of "virtual PEDs," which remain under discussion (JPI Urban Europe/SET Plan Action 3.2, 2020a, p. 6). These solutions not only require investment and engagement from the community within PEDs, but also require materials extraction and workforces outside PEDs such as from solar PV manufacturers, lithium mining for energy storage technology and infrastructures, or data centres for smart grid operations (Levenda et al., 2021; Sovacool, 2021). These characteristics of PEDs might then raise problems with one of the key dimensions of environmental and energy justice which has been at the centre of social sciences' energy research for some time, namely distributive injustice.

In general, energy justice has been concerned with the generation (or worsening) of social inequalities by energy systems and transitions. This can include distributive, recognition and procedural justice (see also sections Recognition justice and people-place relations-Background in PEDs and general definition and Procedural justice-Background in PEDs and general definition below $)^{1}$. These have been shown to be significant factors in public responses to energy and transportation technologies' deployment (Sovacool et al., 2017). Distributive justice is normally defined as the sense of equal distribution of costs and benefits, or of responsibilities and rights (Walker, 2009). As described by Sovacool et al. (2017, p. 677), "costs is how the hazards and externalities of the energy system are disseminated throughout society (...) benefits is how the ownership of and access to modern energy systems and services are distributed throughout society."

\section{Mainstream Approach}

Traditionally, mainstream approaches have mostly focused upon distributive justice as a financial issue, based on a conception of individuals as homo-economicus, namely, as those who take decisions based only upon economic and functional costbenefit analyses (see Batel et al., 2016 for a review). For example, normative approaches to distributive injustice are often concerned with how communities which are locally affected by the deployment of a wind farm can be financially compensated in the most cost-effective way possible for the energy companies (see Wolsink, 2018). Moreoever, they might focus on the extent of financial incentives necessary to motivate citizens to buy electric cars or solar PV for their households, whilst disregarding the fact that this will only benefit a few high-income groups who have economic capital and capabilities to invest in such new

\footnotetext{
${ }^{1}$ More recent and extended conceptualisations of energy justice have also included other dimensions, such as cosmopolitan or global justice, restorative justice and intergenerational justice (Sovacool et al., 2017, 2019a). However, our narrative literature review showed that these dimensions have not been as focused as such by research thus far. Furthermore, we also consider that, within a critical approach, these should be seen as transversal aspects to be included within the other key tenets of energy justice (i.e., distributive, recognition and procedural) since all of these should entail acknowledging the co-construction and implications of peopleenergy relations throughout time and across space, from the global to the local (see Walker, 2009; also Batel and Devine-Wright, 2017).
} 
technologies (Sovacool et al., 2019b). In other words, by focusing on the willingness-to-pay for minimising the visual impact of energy infrastructures (or investing in low-carbon technologies), mainstream approaches assume that local opposition to those infrastructures (or up-take of those technologies) is based mainly on people's economic capacities and concerns (see Wolsink, 2018 for a critical discussion). Hence, this research often quantifies the impacts of a certain energy facility and policy through cost-benefit analyses and related monetary and material compensations for their deployment.

\section{Critical Approach}

However, critical research has also noted that there are other, symbolic, cultural and emotional, dimensions of distributive justice which cannot be quantified and compensated instrumentally. One example is the spiritual relationship of local people with ecological systems. This has been illustrated by Vargas Payera (2018) in Chile, where indigenous' communities resisted the deployment of a geothermal plant given their relations with volcanoes. Past intergroup relations and injustices regarding people-place relations and associated collective memories are also important, however, they are not usually considered in energy projects. This was evident in the deployment of high voltage power lines and wind farms in Wales to connect to the English energy grid, which created local opposition because it was seen as perpetuating the colonial history of England exploiting Wales in past energy projects. In turn, it therefore had a deep impact on people's lives and senses of place (Batel and Devine-Wright, 2017). If these non-quantifiable dimensions of energy projects are not considered, the mal-distribution of costs and benefits can induce several psycho-social harms. These include reduced well-being, depression, and anxiety amongst those who experience these inequalities (Lima and Morais, 2015). Beyond this, other under-acknowledged eco-psycho-geographical impacts of energy infrastructures have also been observed (see Dunlap, 2020).

As such, critical energy justice research has been moving away from normative, aspirational and utopian justice imperatives (which are more characteristic of mainstream approaches), in order to highlight the unjust consequences of current capitalist political economies within an inter-sectional, decolonial framework (Jenkins et al., 2020; Menton et al., 2020). Dunlap and Sullivan (2020) term this problem of distributive injustice as "accumulation-by-alienation" following Harvey's (2018) "accumulation-by-dispossession," an abstraction of economic value from ecological systems (in this case land and energy resources) which alienate their symbolic relation to humans in order to quantify, commodify, and pay it off (see more in section Recognition Justice and People-Place Relations-Background in Peds and General Definition below). Other proposals from critical approaches to distributive justice have suggested the importance of acknowledging and better unveiling the global consequences of transnational energy projects and transitions through concepts such as energy or green colonialism (Batel and Devine-Wright, 2017; Normann, 2021). Both concepts draw attention to the global and historical injustices of energy generation and low-carbon technologies' production as they build upon structural, historical power asymmetries between the privileged and the dispossessed. This has been done by transferring or delegating the cost of energy and related material extractions to other, less powerful, socio-geographical areas, including their inhabitants and ecological systems.

\section{Recognition Justice and People-Place Relations-Background in PEDs and General Definition}

To secure the efficiency and flexibility of the energy system, PEDs may require several features. These include: flexible tariffs to manage the energy demand and supply dynamics; retrofitting houses to improve building stock efficiency; and, altering transportation infrastructure to allow more electric vehicles (SET-Plan Working Group, 2018). However, these changes in energy practises and spatial settings may also affect the physical and social lives of residents in different ways. Without considering the needs of different people such as the poor, the elderly, the homeless, the unemployed and citizen's place relations, PEDs policies and technologies can further exclude them from their design and outcomes, which gives rise to (mis)recognition of justice concerns regarding energy and transport poverty as well as people-place relations.

Recognition injustice is defined as "the processes of disrespect, insult and degradation that devalue some people and some place identities in comparison to others" (Walker, 2009, p. 615). Flexible pricing of electricity or "time of use" tariffing, for example, has been found to disregard or fail to recognise the need of single parents or long hours working parents. Frequently, they have children who often concentrate all family activities at certain times of the day, thus making them pay higher electricity bills than other more flexible households (Sovacool et al., 2019b). In turn, the stigmatisation of places and of associated identities and attachments can occur when the construction of wind turbines and solar panels in a community (or the renovation of its buildings), changes how that community and place are not only experienced (Groves, 2015; Rudolph and Kirkegaard, 2019), but also their socio-economic characteristics. This may lead to community members' physical and/or psychological displacement and related impacts on wellbeing and empowerment (Brown and Perkins, 1992; Manzo and Devine-Wright, 2013; Ropert and Di Masso, 2021).

\section{Mainstream Approach}

Mainstream approaches to recognition justice have focused around household-scale material and economic factors promoting energy and transport poverty. Specifically, these include the affordability and accessibility of energy and transport services to different groups and regions (see Simcock et al., 2021). Scholars have contributed to evaluating affordability by uncovering which demographic groups (i.e., by age, gender, economic status) have high energy and transport spending relative to their income levels (Simcock et al., 2020). By highlighting these vulnerable cases, current policies not only favour targeted economic subsidies, such as reducing energy and transport tariffs for vulnerable regions and households, but also promote behaviour change programs aimed at improving 
the cognitive capacity and energy efficacy of people's behaviours (see Jenkins et al., 2016). However, this type of approach builds upon imperatives of self-responsibility in energy governance, which can in turn create greater stress for those who are already lacking time and resources in their everyday lives, such as single parents, or those who are incapable of implementing changes due to ageing or disability.

Furthermore, the spatialising of domestic and transport energy poverty in mainstream research also has aided policy makers in detecting "energy peripheries" which lack access to networked energy and transport infrastructures (Robinson and Mattioli, 2020). To rectify these stigmatised regions of poverty and unsustainability, many cities in Europe have seen the burgeoning of "green regeneration" projects which renew deprived urban neighbourhoods with green spaces and lowcarbon initiatives, but also increase housing market prices (Ali et al., 2020). By recognising and improving the financial value of the area, this environmental gentrification often leads to the displacement of vulnerable residents who are unable to afford or accommodate such renovations. As their voices and relations with their homes, neighbourhoods and communities are marginalised, this mainstream approach can, in turn, perpetuate energy poverty and marginalisation (de Carvalho and Cornejo, 2018).

\section{Critical Approach}

Critical approaches to this issue have tried to understand why there is energy vulnerability and place stigmatisation in the first instance. They have also sought to explain how this is a result of the misrecognition or non-recognition of certain groups and places at the societal and political level rather than at individual, cognitive levels (Jenkins et al., 2016; Simcock et al., 2021). Research in the feminist energy development field, for example, has contested the distorted view of "gender mainstreaming" in subsidising female-headed families to tackle energy poverty. Such an approach essentialises the vulnerability of women to poverty whilst obscuring the structural cause of said poverty such as gender norms. In turn, this leads to the marginalising of women in need within non-female-headed households (Listo, 2018). In the same vein, the unequal gender distribution of labour, especially in positions of power, might not allow women to participate in the decision-making processes of electricity production. Consequently, this then excludes their needs and lived experiences from project design (Fraune, 2015). Another crucial example is given by Lennon (2017) who highlights the need to acknowledge, examine and contest how colonial legacies shape ethnic-racial inequalities in engaging with and accessing mobility as well as electricity. This emphasises the need not only to act at more structural, societal levels to change systemic inequalities, but also to consider how this might be challenged through local initiatives and practises such as in PEDs (see also Lennon, 2021).

Furthermore, instead of stigmatising some places as poor and unsustainable in order to legitimise economic and environmental development projects as in mainstream approaches, critical research is mindful of other pertinent factors. For instance, how promoted changes in the physical and social composition of buildings, neighbourhoods and cities might deeply affect people's well-being, through further reproducing (or even creating) new exclusions and inequalities (de Carvalho and Cornejo, 2018). As already mentioned, PEDs might displace those who cannot afford a low-carbon settlement from not only a given house or apartment as a building made of bricks, but also from their home, neighbourhood and community, with all their emotional and symbolic meanings and relations as well as associated psycho-social impacts (Manzo and Devine-Wright, 2013). By adopting a more critical approach which argues for a non-static, non-essentialist view of places and groups, PEDs can include the voices of under-represented groups and promote their local, indigenous knowledge, experiences and relations, instead of prescribing top-down, non-contextual and commodified interventions that reproduce exclusions and stigmatised representations of places and of certain groups (Devine-Wright et al., 2019; Ropert and Di Masso, 2021).

\section{Procedural Justice-Background in PEDs and General Definition}

As is already clear from the above, PEDs technological and social innovations require the participation of multiple actors including the local authorities, private companies, and civil society. For example, to encourage citizens to use low-carbon public modes of transport instead of private cars, city planners need to improve the inclusive design of the transport system through public engagement processes so that it can serve the various needs of different groups of the population.

Considered to be a key factor in the social acceptance of energy and transport technology, procedural justice ensures that energy decision-making respects due process and representation (Sovacool et al., 2017). This is because undemocratic processes can create unequitable outcomes to under-represented or misrepresented groups (see recognition justice in section Recognition Justice and People-Place Relations-Background in PEDs and General Definition above). Therefore, under the multi-level governance perspective, institutionalised public participation procedures, such as the United Nations' Agenda 21, are encouraged at the local level (Geissel, 2009) through various democratic and participatory practises. These include public opinion surveys, community consultancy, participatory budgeting, and co-creation workshops (Becker and Naumann, 2017; Itten et al., 2021).

\section{Mainstream Approach}

Current mainstream approaches to public participation mostly conceives of people's negative responses to energy projects as NIMBY- Not in my back yard-and assumes that responses to energy projects are based on ignorance, proximity and selfinterest (Devine-Wright, 2011). Despite other factors that explain better the "back yard motives" (such as place attachment and energy justice issues as mentioned above) (see Wolsink, 2007; Devine-Wright and Howes, 2010; Batel, 2020), NIMBY-ism is still used by many researchers, policy-makers and energy companies. NIMBY-ism interprets local resident's opposition to energy projects as irrational, selfish and ignorant by lacking objective information. This leads to a "tokenistic level" of citizens" 
engagement, including informing, consulting and placation (Arnstein, 1969). These are often regarded as sufficient to create social acceptance in an instrumental way (see also DevineWright, 2011; Jenkins et al., 2016; Levenda et al., 2020). For example, qualitative research into public consultation and participatory budgeting points out that invited participation, understood as one-way dialogue or discursive justification of interventions from formal institutions towards citizens, is often used to simulate participation and pre-empt social conflicts (Cuppen, 2018; Carvalho et al., 2019; Santos et al., 2019). In other words, consensus-making techniques which reduce political debate to technical and management activities make it seem like all voices are heard and considered. Of course, this is done to ease local resistance, even when final decisions are still mainly based on cost-benefit analyses and regulatory constraints that benefit authorities and corporations (Santos et al., 2019).

\section{Critical Approach}

Critical approaches to procedural justice propose ways to overcome tokenistic practises of participation by challenging the biased representations about the public often held by energy project developers and policy-makers (Walker et al., 2010a,b; Barnett et al., 2012). These powerful stakeholders tend to negatively represent citizens' opposition towards local energy projects as merely being NIMBY, as outlined above. Critical inquiries into this issue pay attention specifically to the unequal power relations between experts and citizens within technocratic, low-carbon transitions and governance, and how those tend to preclude citizens from actually being able to influence decisionmaking processes since they are projected until decommission (Knudsen et al., 2015; Carvalho et al., 2019). Research in this area, therefore, has been challenging developers' conventional imaginaries of the public. By contrast, it seeks to advance alternative representations of the public as non-homogenous and non-static, but rather indigenous, common-sense, experiential, and affective (Rodhouse et al., 2021). Thus, their lived experiences and bottom-up forms of knowledge are legitimate and relevant to include in energy related decision-making processes (VelascoHerrejon and Bauwens, 2020; Elkjær et al., 2021).

The recent co-creation turn in governance practises has the potential to empower citizens and communities alongside traditional experts for collaborative knowledge generation and decision-making by reconsidering citizen's roles from consulted citizens to active co-producers and political actors in the participative process (Elkjær et al., 2021). Indeed, Itten and colleagues' study (Itten et al., 2021) has shown that co-creation is a potential solution for sustainable heat transitions as it is possible to see how citizens and house owners' shared meanings of heating. In turn, this has helped stakeholders to include those meanings in their energy programme design. Another study about living labs in Switzerland concludes that this type of cocreation could create a protected space for citizens, innovation entities and public authorities in order to build reciprocal trust to discuss contested topics such as future mobility scenarios (Cellina et al., 2020). Furthermore, community renewable energy ecologies (CREE) have been discussed as having a more transformative potential amongst co-creation practises as they are built on principles of collective ethic-political decisionmaking, based on care and affective relations amongst humans and non-humans. Hence, CREE adopt "non-capitalist relations of ownership, production, exchange and circulation" (Siamanta, 2021, p. 47).

\section{Routines, Capabilities and Lived Experiences-Background in PEDs and General Definition}

Regarding energy efficiency aspects, energy users (including transport users and property owners) are the main targets of the PEDs framework (JPI Urban Europe/SET Plan Action 3.2, 2020b). With the availability of energy efficient appliances, energy users are expected to adopt more energy conservation behaviours based upon feedback from smart meters. Similarly, house or building owners should invest in retrofitting to save energy costs in the long run. Furthermore, to adapt to energy flexibility, energy users are responsible for adjusting their practises to avoid high electricity prices and accommodate for low energy supply scenarios.

A large part of energy consumption behaviours-such as heating, cleaning and showering-are found to be routine and habitual (Hess et al., 2018). Hence, how to change inefficient routines and set up new habits have been the main aims of many efficiency and flexibility interventions in smart cities. This trend is captured in Sovacool (2014) review paper which concludes that human-centred research has paid more attention to the routines and habits of energy users instead of the general technological and economic configurations shaping said routines.

\section{Mainstream Approach}

A vast amount of research in psychology and behavioural economics has been invested in understanding and changing individual patterns of energy consumption (Burger et al., 2015; Steg et al., 2015). This mainstream approach examines how individuals' routines are formed not only by personal attitudes towards environmental problems based on their values and beliefs, but also by social norms i.e., the perceived expectations and behaviours of others (Ingeborgrud et al., 2020). Within this approach, recommended policies tend to use targeted communication strategies to appeal to audiences' values and beliefs (Ingeborgrud et al., 2020). This can include cost-effective benefits for utilitarian values and environmental impacts for altruistic, bio-spheric concerns (Hess et al., 2018). It also harnesses social norms to nudge energy users into energy saving behaviours, for example, via feedback of average household energy consumption on a smart meter (DellaValle and Sareen, 2020). For more effectively targeted behaviour change policies, mainstream research has been predicting which socio-demographic groups are more impacted by which underlying psychological factors. These include: beliefs and attitudes; motives and intentions; perceived behavioural control; cost-benefit appraisals; and, personal and social norms (Frederiks et al., 2015). However, these nudging and economic incentive interventions (which dominate in energy governance and policies) have been shown to have a short run, individual impact, and even counter-productive outcomes 
(Dholakia et al., 1983; Roberts, 2017; see more in critical approach below).

\section{Critical Approach}

More recent, critical-led research, points out that the "energy efficiency" imperative in energy conservation behaviour research and intervention not only "purifies" energy consumption from its everyday practises (Shove, 2018) but also assumes consumerism as usual, i.e., energy users are locked into the consumer culture of appliances and lifestyles that require extensive and continuous energy consumption (McDonald et al., 2017). Furthermore, smart technologies for energy efficiency could lead to a "rebound effect" by increasing overall energy usage after saving from energy efficient appliances and practises, which could render the effort of reducing environmental impacts from energy consumption futile in human-centric PEDs (Shove, 2018).

Critical research on this, such as that utilising social practise theory, sees rhythm of life, working schedules, and infrastructures as structural constraints to changing routines (Murtagh et al., 2014; Sovacool et al., 2018). For instance, a study on smart-meters in France points out that citizens complain about the pre-setting of some home devices that they are unable to turn-off (Bertoldo et al., 2015). Consequently, they lose their capability to control and thus sense of agency in their interaction with energy facilities (Marres, 2012; Sadowski and Levenda, 2020). In another example, qualitative research based on social practises theory has unravelled how practises of heating the homes of old residents in the UK closely connects to the cultural meaning of comfort, cosiness and glow. This associates heating the house with burning wood, or turning on the heater even when other less energy-intensive actions could be taken, such as wearing more clothes or insulating the house to ensure thermal comfort (Devine-Wright et al., 2014; Wrapson and Devine-Wright, 2014). Critical research on mobility also finds that the routine of frequent, low-cost and private travel experiences (or hypermobility) is deeply driven by the dominant neoliberal connotations of autonomy and individual freedom, but also social status in relation to personal success as well as wider frames about national progress (Barr, 2018). As such, more structural, political and economic changes must happen to allow for less energy intensive practises within a degrowth and energy justice framework (Schneider et al., 2010).

In summary, critical approaches call for the need of a humancentric approach in PEDs which pays more attention to the lived experiences and valued capabilities of energy users, such as keeping good health, feeling respected, preserving indigenous identities and feeling a sense of agency over one's life and community (see Edwards et al., 2016; Velasco-Herrejon and Bauwens, 2020; also Holifield et al., 2017). By connecting these lived experiences and valued capabilities to existent social, political, economic and cultural conditions, critical approaches allow for the modification of routines and practises by allowing the re-configuration of their meanings without negatively impacting people's and ecosystems' well-being.

\section{CONCLUSIONS}

As emerging PEDs are currently proposed based on the technocratic and economic traditions of the energy sector, a better understanding of the human and social dimensions of PEDs is needed to break the "silo thinking" found therein (Yoo et al., 2020). However, SSH energy research has already started to show that not all approaches to considering the social dimensions of energy systems and related initiatives towards increased environmental sustainability are similar. For instance, some tend to reproduce and further reify the political economy of the fossil-fuel status quo and associated neglect of the social and environmental injustices and inequalities it has created and continues to accentuate. However, critical SSH approaches work towards unveiling and contesting those injustices and inequalities. As such, this paper, based on a narrative-style inter-disciplinary literature review of critical SSH energy research (with a special focus on environmental and social psychology), aimed to develop a critical framework towards a human-centric approach to PEDs. Specifically, one that is able to consider and integrate issues of justice, inclusion and well-being. As a result, the critical framework that we proposed is based on five interrelated dimensions: uncertainty; risk perception and trust; distributive justice; recognition justice and people-place relations; procedural justice; and, routines, capabilities, and lived experiences.

As such, this paper also contributes to advance SSH scholarship on energy and environmental justice in general, and specifically in relation to people's engagements with renewable and smart energy transitions. It does so by shedding light on why and how a critical approach is needed (see also Menton et al., 2020), but also by contributing some insights to this literature from social and environmental psychology perspectives. These are: (i) the role of socio-historical dimensions and related collective memories and psychosocial impacts on distributive injustice; (ii) the consideration of place attachment and associated psychosocial subjectivities in relation to recognition justice; and, (iii) the power dynamics between lay and experts which shape the imagined roles and agency of the public in procedural justice concerns.

In this vein, this paper contributes to a more reflexive and holistic view in understanding the human dimension in PEDs. Through the critical review and framework, it is noticeable that the status quo or mainstream approaches tend to study different factors separately. They also quantify their effects on individuals by isolating them from other contextual, social, and political relevant dimensions. On the contrary, critical perspectives regard this abstraction and alienation process as problematic. This critical perspective, therefore, allows us to consider, discuss and include specific measures and interventions in the deployment of PEDs. These measures consider energy consumption and production not as a given, but as social, cultural, political, economic and collective endeavours. To that end, they also impact upon their specific components and configurations when being implemented (see Sovacool, 2014). 


\section{DISCUSSION AND RECOMMENDATIONS FOR FUTURE RESEARCH AND POLICIES}

As a last remark, this paper discusses some recommendations for future research and policy interventions to achieve humancentric PEDs which are attentive to justice, inclusion, and wellbeing of citizens and ecological systems alike.

\section{Assess the Whole Life-Cycle of Energy Systems in PEDs Impact Analysis}

Instead of only tackling the downstream social and ecological consequences of energy systems in local areas, critical approaches recommend that researchers and policy makers redefine and recognise energy justice as relevant across local to global scales to avoid shifting the social, environmental, psychological and health costs of sustainable energy transitions from the Global North to the Global South, or to more vulnerable and marginalised communities and territories in general (Batel and DevineWright, 2020; Menton et al., 2020). This implies a more reflexive connection of energy consumption with energy production. This would consider the whole lifecycle of the infrastructures and technologies needed to deploy PEDs, such as lithium extraction for batteries and storage for EV. As Sovacool (2021, p. 14) suggests: "more attention to multi-scalar and whole-systems thinking would better appreciate how climate mitigation efforts depend on resource extraction and mining, manufacturing, transport and construction, policy and planning, operation and use, and disposal and waste streams. Whole systems approaches would ensure that the suffering of others is no longer obscured or distorted by distance."

\section{Unveil and Challenge the Political Economy of Conventional Interventions to Encourage Transformative Alternatives for PEDs' Social-Ecological-Technological Configurations}

By inspiring collective action against the import of energy sources that are considered unethical, such as the divestment movement against fossil fuel-based energy (Healy and Barry, 2017), critical approaches challenge the "capitalist valuation" [...] towards deeper contestation of the alienating accumulation structures effected through neoliberal environmental governance" (Dunlap and Sullivan 2020, p.570). Hence, it can contribute to creating "an alliance of the dispossessed, including a coalition of the global social and environmental justice movements" (Kallis et al., 2018, p. 29). Alternatives to the dominant neoliberal capitalist rationality of energy governance have been explored in post-development, decolonisation and degrowth pathways. These conceptualise production as based on alternative socioecologies which are more community-based, circular, inclusive and based on mutual aid (Nirmal and Rocheleau, 2019; Siamanta, 2021). More focus should be given to the lived experiences, everyday practices and informal economies of some selfgoverned communities around the world and in some cities in the Global South (e.g., Butcher and Maclean, 2018). In turn, this can challenge neoliberal capitalist practises and offer alternative configurations for human-centric PEDs.

\section{Prioritise Human and Ecosystems Well-Being and Lived Experiences in PEDs Design}

PEDs could foster transformative, structural changes by recognising and including other concerns in their development and implementation such as communalist values and well-being (Edwards et al., 2016) as well as equity principles (Sovacool et al., 2017). These could be deployed to address energy poverty and inequalities at their source. "Feminist energy systems," for example, would propose that PEDs' energy technologies and economic model need to be contextualised to respect the specific needs of different groups of people in different localities (Bell et al., 2020). To do so, an empirical focus on lived experiences, routines and valued capabilities, which engages with communities through ethnography, living labs, walking and in-depth interviews, could create opportunities for energy citizens to re-negotiate and question how they are pushed by and embedded in both every day, needed demands that they value, but also the larger demands of energy systems and associated political economies (Waitt et al., 2016; Barr, 2018).

\section{Empowered Citizens and Communities Through Co-creation of PEDs}

The aim should then be to only deploy PEDs innovations (such as micro-generation, smart meters, retrofitted homes, electric vehicles, district waste heat etc.) by openly co-creating them with citizens. Attention must be paid to their concerns and values, and from a collective, local to global perspective, being considerate of social and ecological systems alike (Williams et al., 2014; Devine-Wright et al., 2019). This move from public participation to co-creation of PEDs not only requires the reexamination of mainstream knowledge, i.e., the decolonisation of energy (Lennon, 2017), but also the valuation of the lay public's energy conceptions through the reappraisal of indigenous and informal energy knowledge and practises (Normann, 2021). Future research should therefore further inquire into how this can be done outside structural, institutional constraints, and be based on bottom-up, community-led and aimed initiatives. The goal of such an approach would be a sustainable, just and socioenvironmental alternative to State and corporate-led smart and renewable energy transitions.

In conclusion, critical approaches to human dimensions in PEDs help to uncover the structural exclusions implied in many current "sustainable" governance structures and associated political economies of smart cities initiatives including PEDs. They are also vital to unearth relevant psycho-social dimensions and impacts by proactively reaching out for often ignored alternative stories and people. As such, critical approaches have the potential to support PEDs deployment via more just and equitable human-centric local energy transitions. This means to reveal, in a clear and evidence-based way, why and how these objectives are not "truly" feasible unless we start to actually transform not only the energy system, but also the politics of 
energy towards degrowth and an ethics of care and responsibility for all socio-ecological systems both locally and globally, and in the short and long terms.

\section{AUTHOR CONTRIBUTIONS}

$\mathrm{M}-\mathrm{TN}$ and SB reviewed the literature, conceptualized, and wrote the paper.

\section{FUNDING}

This work was funded by European Union's Horizon 2020 research and innovation programme under the Marie

\section{REFERENCES}

Ali, L., Haase, A., and Heiland, S. (2020). Gentrification through green regeneration? Analyzing the interaction between inner-city green space development and neighborhood change in the context of regrowth: the case of Lene-Voigt-Park in Leipzig, Eastern Germany. Land 9:24. doi: 10.3390/land 9010024

Ambrose, A. (2020). Walking with Energy: Challenging energy invisibility and connecting citizens with energy futures through participatory research. Futures 117:102528. doi: 10.1016/j.futures.2020.102528

Arnstein, S. R. (1969). A ladder of citizen participation. J. Am. Plann. Assoc. 35, 216-224. doi: 10.1080/01944366908977225

Barnett, J., Burningham, K., Walker, G., and Cass, N. (2012). Imagined publics and engagement around renewable energy technologies in the UK. Public Underst. Sci. 21, 36-50. doi: 10.1177/0963662510365663

Barr, S. (2018). Personal mobility and climate change. Wiley Interdicip. Rev. Clim. Change 9:e542. doi: 10.1002/wcc.542

Batel, S. (2020). Research on the social acceptance of renewable energy technologies: past, present and future. Energy Res. Soc. Sci. 68:101544. doi: 10.1016/j.erss.2020.101544

Batel, S., Castro, P., Devine-Wright, P., and Howarth, C. (2016). Developing a critical agenda to understand pro-environmental actions: contributions from social representations and social practices theories. Wiley Interdicip. Rev. Clim. Change 7, 727-745. doi: 10.1002/wcc.436

Batel, S., and Devine-Wright, P. (2017). Energy colonialism and the role of the global in local responses to new energy infrastructures in the UK: a critical and exploratory empirical analysis. Antipode 49, 3-22. doi: 10.1111/anti. 12261

Batel, S., and Devine-Wright, P. (2020). Using NIMBY rhetoric as a political resource to negotiate responses to local energy infrastructure: a power line case study. Local Environ. 25, 338-350. doi: 10.1080/13549839.2020.17 47413

Batel, S., and Rudolph, D. (eds.). (2021). A Critical Approach to the Social Acceptance of Renewable Energy Infrastructures: Going Beyond Green Growth and Sustainability. New York, NY: Springer.

Beck, U. (1992). From industrial society to the risk society: questions of survival, social structure and ecological enlightenment. Theor. Cult. Soc. 9, 97-123. doi: $10.1177 / 026327692009001006$

Becker, S., and Naumann, M. (2017). Energy democracy: mapping the debate on energy alternatives. Geogr. Compass 11, 1-13. doi: 10.1111/gec3.12321

Bell, S. E., Daggett, C., and Labuski, C. (2020). Toward feminist energy systems: why adding women and solar panels is not enough?. Energy Res. Soc. Sci. 68:101557. doi: 10.1016/j.erss.2020.101557

Bertoldo, R., Poumadère, M., and Rodrigues, L. C. (2015). When meters start to talk: the public's encounter with smart meters in France. Energy Res. Soc. Sci. 9, 146-156. doi: 10.1016/j.erss.2015.08.014

Bickerstaff, K. (2004). Risk perception research: socio-cultural perspectives on the public experience of air pollution. Environ. Int. 30, 827-840. doi: 10.1016/j.envint.2003.12.001
Sklodovska-Curie Actions, Innovative Training Networks, Grant Agreement No. 812730. The work of SB was also funded by Portuguese national funds through FCT - Fundação para a Ciência e a Tecnologia, I.P., in the context of Norma Transitória - DL57/2016/CP1359/CT0039.

\section{ACKNOWLEDGMENTS}

The authors would like to thank the reviewers for their comments, as well as, the support of Ross James Wallace for proofreading, and CIS, ISCTE-IUL's administrative support for researchers.

Bickerstaff, K. J., Simmons, P., and Pidgeon, N. (2008). Constructing responsibilities for risk: negotiating citizen - state relationships. Environ. Plann. A. 40, 1312-1330. doi: 10.1068/a39150

Brown, B. B., and Perkins, D. D. (1992). "Disruptions in place attachment," in Place Attachment, eds I. Altman, and S.M. Low (New York, NY: Springer US), 279-304. doi: 10.1007/978-1-4684-8753-4_13

Burger, P., Bezençon, V., Bornemann, B., Brosch, T., Carabias-Hütter, V., Farsi, M., et al. (2015). Advances in understanding energy consumption behavior and the governance of its change - outline of an integrated framework. Front. Energy Res. 3, 1-19. doi: 10.3389/fenrg.2015.00029

Butcher, M., and Maclean, K. (2018). Gendering the city: the lived experience of transforming cities, urban cultures and spaces of belonging. Gend. Place Cult. Luxembourg 25, 686-694. doi: 10.1080/0966369X.2018.1462773

Caramizaru, E., and Uihlein, A. (2020). Energy communities: an overview of energy and social innovation, EUR 30083 EN. Luxembourg: Publications Office of the European Union.

Carvalho, A., Pinto-Coelho, Z., and Seixas, E. (2019). Listening to the public-enacting power: citizen access, standing and influence in public participation discourses. J. Environ. Policy Plan. 21, 563-576. doi: 10.1080/1523908X.2016.1149772

Casanova, M. L., Menezes, I., Lawthom, R., and Coimbra, J. L. (2019). Precarious living: the social origins of uncertainty. Port. J. Soc. Sci. 18, 319-340. doi: 10.1386/pjss_00013_1

Cellina, F., Castri, R., Simão, J. V., and Granato, P. (2020). Co-creating appbased policy measures for mobility behavior change: a trigger for novel governance practices at the urban level. Sustain. Cities Soc. 53:101911. doi: 10.1016/j.scs.2019.101911

Clayton, S., Devine-Wright, P., Swim, J., Bonnes, M., Steg, L., Whitmarsh, L., et al. (2016). Expanding the role for psychology in addressing environmental challenges. Am. Psychol. 71, 199-215. doi: 10.1037/a0039482

Cori, L., Bianchi, F., Cadum, E., and Anthonj, C. (2020). Risk perception and covid-19. Int. J. Environ. Res. Public Health 17:3114. doi: 10.3390/ijerph1 7093114

Cuppen, E. (2018). The value of social conflicts. Critiquing invited participation in energy projects. Energy Res. Soc. Sci. 38, 28-32. doi: 10.1016/j.erss.2018.01.016

de Carvalho, L. P., and Cornejo, M. (2018). Towards a critical approach to place attachment: a review in contexts of infringement of the right to adequate housing. Athenea Digit. 18, 1-39. doi: 10.5565/rev/athenea.2004

DellaValle, N., and Sareen, S. (2020). Nudging and boosting for equity? Towards a behavioural economics of energy justice. Energy Res. Soc. Sci. 68:101589. doi: 10.1016/j.erss.2020.101589

Devine-Wright, P. (2011). Public engagement with large-scale renewable energy technologies: Breaking the cycle of NIMBYism. Wiley Interdicip. Rev. Clim. Change 2, 19-26. doi: 10.1002/wcc.89

Devine-Wright, P., and Howes, Y. (2010). Disruption to place attachment and the protection of restorative environments: a wind energy case study. J. Environ. Psychol. 30, 271-280.

Devine-Wright, P., Smith, J., Batel, S., Devine-Wright, P., Smith, J., and Batel, S. (2019). "Positive parochialism," local belonging and ecological concerns: 
revisiting common ground's parish maps project. Trans. Inst. Br. Geogr. 44, 407-421. doi: 10.1111/tran.12282

Devine-Wright, P., Wrapson, W., Henshaw, V., and Guy, S. (2014). Low carbon heating and older adults: comfort, cosiness and glow. Build. Res. Inf. 42, 288-299. doi: 10.1080/09613218.2014.883563

Dholakia, R. R., Dholakia, N., and Firat, A. F. (1983). From social psychology to political economy: a model of energy use behavior. J. Econ. Psychol. 3, 231-247. doi: 10.1016/0167-4870(83)90004-1

Di Masso, A. (2012). Grounding citizenship: toward a political psychology of public space. Polit. Psychol. 33, 123-143. doi: 10.1111/j.1467-9221.2011.00866.x

Douglas, M., and Wildavsky, A. (1983). Risk and Culture: An Essay on the Selection of Technological and Environmental Dangers. Berkeley, CA: University of California Press. doi: 10.1525/9780520907393

Dunlap, A. (2020). Bureaucratic land grabbing for infrastructural colonization: renewable energy, L'Amassada, and resistance in southern France. Hum. Geogr. 13, 109-126. doi: 10.1177/1942778620918041

Dunlap, A., and Sullivan, S. (2020). A faultline in neoliberal environmental governance scholarship? Or, why accumulation-by-alienation matters. Environ. Plan. E. Nat. Space 3, 552-579. doi: 10.1177/2514848619874691

Edwards, G. A. S., Reid, L., and Hunter, C. (2016). Environmental justice, capabilities, and the theorization of well-being. Prog. Hum. Geogr. 40, 754-769. doi: 10.1177/03091325156 20850

Elkjær, L. G., Horst, M., and Nyborg, S. (2021). Identities, innovation, and governance: a systematic review of co-creation in wind energy transitions. Energy Res. Soc. Sci. 71:101834. doi: 10.1016/j.erss.2020.1 01834

European Commission (2018). 2030 Climate \& Energy Framework - Climate Action. 2030 Climate \& Energy Framework. Available online at: https://ec. europa.eu/clima/policies/strategies/2030_en (accessed August 13, 2020).

European Commission (2019). "Clean Energy for All Europeans," in Euroheat and power (English Edition), Vol. 14. Luxembourg: EU Publications.

Eurostat (2020). "Greenhouse Gas Emission Statistics - Emission Inventories Statistics Explained.” Eurostat. 2020. Available online at: https://ec.europa.eu/ eurostat/statisticsexplained/ (accessed August 13, 2020).

Fraune, C. (2015). Gender matters: women, renewable energy, and citizen participation in Germany. Energy Res. Soc. Sci. 7, 55-65.

Frederiks, E. R., Stenner, K., and Hobman, E. V. (2015). The sociodemographic and psychological predictors of residential energy consumption: a comprehensive review. Energies 8, 573-609. doi: 10.3390/en8010573

Geissel, B. (2009). Participatory governance: hope or danger for democracy? A case study of local agenda 21. Local Gov. Stud. 35, 401-414. doi: 10.1080/03003930902999522

Giddens, A. (1999). Risk and responsibility. Modern Law Rev. 62, 1-10. doi: $10.1111 / 1468-2230.00188$

Greenberg, M. R. (2014). Energy policy and research: the underappreciation of trust. Energy Res. Soc. Sci. 1, 152-160. doi: 10.1016/j.erss.2014.02.004

Groves, C. (2015). The bomb in my backyard, the serpent in my house: environmental justice, risk, and the colonisation of attachment. Environ. Polit. 24, 853-873. doi: 10.1080/09644016.2015.1067348

Groves, C., Munday, M., and Yakovleva, N. (2013). Fighting the pipe: neoliberal governance and barriers to effective community participation in energy infrastructure planning. Environ. Plann. C. Gov. Policy 31, 340-356. doi: $10.1068 / \mathrm{c} 11331 \mathrm{r}$

Guerreiro, S., Batel, S., Lima, M. L., and Moreira, S. (2015). Making energy visible: sociopsychological aspects associated with the use of smart meters. Energy Efficiency 8, 1149-1167. doi: 10.1007/s12053-015-9 344-4

Harvey, D. (2018). Universal alienation. J. Cult. Res. 22, 137-150. doi: 10.1080/14797585.2018.1461350

Healy, N., and Barry, J. (2017). Politicizing energy justice and energy system transitions: Fossil fuel divestment and a "just transition." Energy Policy 108, 451-459. doi: 10.1016/j.enpol.2017. 06.014

Hess, A. K., Samuel, R., and Burger, P. (2018). Informing a social practice theory framework with social-psychological factors for analyzing routinized energy consumption: a multivariate analysis of three practices. Energy Res. Soc. Sci. 46, 183-193. doi: 10.1016/j.erss.2018.06.012
Holifield, R., Chakraborty, J., and Walker, G. (eds.). (2017). The Routledge Handbook of Environmental Justice. London: Routledge. doi: 10.4324/9781315678986

Ingeborgrud, L., Heidenreich, S., Ryghaug, M., Skjølsvold, T. M., Foulds, C., Robison, R., et al. (2020). Expanding the scope and implications of energy research: a guide to key themes and concepts from the social sciences and humanities. Energy Res. Soc. Sci. 63:101398. doi: 10.1016/j.erss.2019.101398

Itten, A., Sherry-brennan, F., Hoppe, T., Sundaram, A., and Devine-wright, P. (2021). Energy research \& social science co-creation as a social process for unlocking sustainable heating transitions in Europe. Energy Res. Soc. Sci. 74:101956. doi: 10.1016/j.erss.2021.101956

Jenkins, K., McCauley, D., Heffron, R., Stephan, H., and Rehner, R. (2016). Energy justice: a conceptual review. Energy Res. Soc. Sci. 11, 174-182. doi: 10.1016/j.erss.2015.10.004

Jenkins, K. E. H., Stephens, J. C., Reames, T. G., and Hernández, D. (2020). Towards impactful energy justice research: transforming the power of academic engagement. Energy Res. Soc. Sci. 67:101510. doi: 10.1016/j.erss.2020.101510

Joffe, H. (2003). Risk: from perception to social representation. Br. J. Soc. Psychol. 42, 55-73. doi: 10.1348/014466603763276126

JPI Urban Europe/SET Plan Action, 3.2 (2020a). Europe Towards Positive Energy Districts. PED Booklet. Vienna: JPI Urban Europe.

JPI Urban Europe/SET Plan Action, 3.2 (2020b). White Paper on PED Reference Framework for Positive Energy Districts and Neighbourhoods. Available online at: https://jpi-urbaneurope.eu/ped/

Kallis, G., Kostakis, V., Lange, S., Muraca, B., Paulson, S., and Schmelzer, M. (2018). Research on degrowth. Annu. Rev. Environ. Res. 43, 291-316. doi: 10.1146/annurev-environ-102017-025941

Knudsen, J. K., Wold, L. C., Aas, Ø., Kielland Haug, J. J., Batel, S., DevineWright, P., et al. (2015). Local perceptions of opportunities for engagement and procedural justice in electricity transmission grid projects in Norway and the UK. Land Use Policy 48, 299-308. doi: 10.1016/j.landusepol.2015.04.031

Lennon, B., Dunphy, N., Gaffney, C., Revez, A., Mullally, G., and O’Connor, P. (2020). Citizen or consumer? Reconsidering energy citizenship. J. Environ. Policy Plan. 22, 184-197. doi: 10.1080/1523908X.2019.1680277

Lennon, M. (2017). Decolonizing energy: black lives matter and technoscientific expertise amid solar transitions. Energy Res. Soc. Sci. 30, 18-27. doi: 10.1016/j.erss.2017.06.002

Lennon, M. (2021). Energy transitions in a time of intersecting precarities: from reductive environmentalism to antiracist praxis. Energy Res. Soc. Sci. 73:101930. doi: 10.1016/j.erss.2021.101930

Levenda, A. M., Behrsin, I., and Disano, F. (2021). Renewable energy for whom? A global systematic review of the environmental justice implications of renewable energy technologies. Energy Res. Soc. Sci. 71:101837. doi: 10.1016/j.erss.2020.101837

Levenda, A. M., Keough, N., Rock, M., and Miller, B. (2020). Rethinking public participation in the smart city. Can. Geogr. 64, 344-358. doi: 10.1111/cag.12601

Lima, M. L. (2004). On the influence of risk perception on mental health: living near an incinerator. J. Environ. Psychol. 24, 71-84. doi: 10.1016/S0272-4944(03)00026-4

Lima, M. L. (2006). Predictors of attitudes towards the construction of a waste incinerator: two case studies. J. Appl. Soc. Psychol. 36, 441-466. doi: 10.1111/j.0021-9029.2006.00014.x

Lima, M. L., Barnett, J., and Vala, J. (2005). Risk perception and technological development at a societal level. Risk Anal. 25, 1229-1239. doi: 10.1111/j.1539-6924.2005.00664.x

Lima, M. L., and Castro, P. (2005). Cultural theory meets the community: worldviews and local issues. J. Environ. Psychol. 25, 23-35. doi: 10.1016/j.jenvp.2004.11.004

Lima, M. L., and Morais, R. (2015). Lay perceptions of health and environmental inequalities and their associations to mental health. Cadernos de Saúde Pública 31, 2342-2352. doi: 10.1590/0102-311X00105714

Listo, R. (2018). Gender myths in energy poverty literature: a critical discourse analysis. Energy Res. Soc. Sci. 38, 9-18. doi: 10.1016/j.erss.2018.01.010

Manzo, L., and Devine-Wright, P. (2013). Place Attachment: Advances in Theory, Methods and Applications. Routledge.

Marres, N. (2012). Material Participation: Technology, the Environment and Everyday Publics. London: Palgrave Macmillan UK. doi: $10.1057 / 9781137029669$ 
McDonald, M., Gough, B., Wearing, S., and Deville, A. (2017). Social psychology, consumer culture and neoliberal political economy. J. Theor. Soc. Behav. 47, 363-379. doi: 10.1111/jtsb.12135

Menton, M., Larrea, C., Latorre, S., Martinez-Alier, J., Peck, M., Temper, L., et al. (2020). Environmental justice and the SDGs: from synergies to gaps and contradictions. Sustain. Sci. 15, 1621-1636.

Murtagh, N., Gatersleben, B., and Uzzell, D. (2014). A qualitative study of perspectives on household and societal impacts of demand response. Technol. Anal. Strat. Manage. 26, 1131-1143. doi: 10.1080/09537325.2014.974529

Nirmal, P., and Rocheleau, D. (2019). Decolonizing degrowth in the postdevelopment convergence: questions, experiences, and proposals from two Indigenous territories. Environ. Plan. E. Nat. Space 2, 465-492. doi: $10.1177 / 2514848618819478$

Normann, S. (2021). Green colonialism in the Nordic context: Exploring Southern Saami representations of wind energy development. J. Commun. Psychol. 49, 77-94.

Pearsall, H., and Anguelovski, I. (2016). Contesting and resisting environmental gentrification: Responses to new paradoxes and challenges for urban environmental justice. Sociol. Res. Online 21, 121-127. doi: 10.5153/sr o.3979

Räthzel, N., and Uzzell, D. (2019a). Critical Psychology - 'Kritische Psychologie' : challenging environmental behavior change strategies. Annu. Rev. Crit. Psychol. $16,1375-1413$

Räthzel, N., and Uzzell, D. (2019b). The future of work defines the future of humanity and all living species. Int. J. Labour Res. 9, 145-171.

Roberts, J. (2017). Nudge-proof: distributive justice and the ethics of nudging. Michigan Law Rev. 116, 1045-1066. Available online at: https://repository.law. umich.edu/mlr/vol116/iss6/13

Robinson, C., and Mattioli, G. (2020). Double energy vulnerability: spatial intersections of domestic and transport energy poverty in England. Energy Res. Soc. Sci. 70:101699. doi: 10.1016/j.erss.2020.101699

Rodhouse, T. S. G. H., Pesch, U., Cuppen, E. H. W. J., and Correljé, A. F. (2021). Public agency and responsibility in energy governance: a Q study on diverse imagined publics in the Dutch heat transition. Energy Res. Soc. Sci. 77:102046. doi: $10.1016 /$ j.erss.2021.102046

Rolfe, S. (2018). Governance and governmentality in community participation: the shifting sands of power, responsibility and risk. Soc. Policy Soc. 17, 579-598. doi: $10.1017 /$ S1474746417000410

Ropert, T., and Di Masso, A. (2021). Living there, leaving there: identity, sociospatial mobility, and exclusion in "Stigmatized Neighborhoods." Polit. Psychol. 42, 53-69. doi: 10.1111/pops.12682

Rudolph, D., Kirkegaard, J., Lyhne, I., Clausen, N. E., and Kørnøv, L. (2017). Spoiled darkness? Sense of place and annoyance over obstruction lights from the world's largest wind turbine test centre in Denmark. Energy Res. Soc. Sci. 25, 80-90. doi: 10.1016/j.erss.2016.12.024

Rudolph, D., and Kirkegaard, J. K. (2019). Making space for wind farms: practices of territorial stigmatisation in rural Denmark. Antipode 51, 642-663. doi: 10.1111/anti.12428

Ryghaug, M., Skjølsvold, T. M., and Heidenreich, S. (2018). Creating energy citizenship through material participation. Soc. Stud. Sci. 48, 283-303. doi: $10.1177 / 0306312718770286$

Sadowski, J., and Levenda, A. M. (2020). The anti-politics of smart energy regimes. Polit. Geogr. 81:102202. doi: 10.1016/j.polgeo.2020.1 02202

Santos, M., Batel, S., and Gonçalves, M. E. (2019). Participatory budgeting in the age of post-politics: Examining the discourses of citizens and representatives of expert-political systems in three municipalities in Portugal. Port. J. Soc. Sci. 18, 153-172. doi: 10.1386/pjss_00003_1

Schneider, F., Kallis, G., and Martinez-Alier, J. (2010). Crisis or opportunity? Economic degrowth for social equity and ecological sustainability. Introduction to this special issue. J. Clean. Prod. 18, 511-518. doi: 10.1016/j.jclepro.2010.01.014

Scoones, I., and Stirling, A. (2020). The Politics of Uncertainty. Oxford: Routledge. doi: $10.4324 / 9781003023845-1$

Scoones, I., Stirling, A., and van Zwanenberg, P. (2020). "The unravelling of technocratic orthodoxy?", in The Politics of Uncertainty, eds I. Scoones and A. Stirling (Oxford: Routledge), 58-72. doi: 10.4324/9781003023 $845-4$
SET-Plan Working Group (2018). Europe to Become a Global Role Model in Integrated, Innovative Solutions for the Planning, Deployment, and Replication of Positive Energy Districts. In SET-Plan Action No 3.2 Implementation plan, 1-72. Available online at :https://setis.ec.europa.eu/system/files/setplan_smartcities_ implementationplan.pdf (accessed January 3, 2021).

Shove, E. (2018). What is wrong with energy efficiency? Build. Res. Inf. 46, 779-789. doi: 10.1080/09613218.2017.1361746

Siamanta, Z. C. (2021). Conceptualizing alternatives to contemporary renewable energy development: Community Renewable Energy Ecologies (CREE). J. Polit. Ecol. 28, 47-69. doi: 10.2458/jpe.2297

Sikder, S. K., Eanes, F., Asmelash, H. B., Kar, S., and Koetter, T. (2016). The contribution of energy-optimized urban planning to efficient resource use-a case study on residential settlement development in Dhaka City, Bangladesh. Sustainability (Switzerland) 8:119. doi: 10.3390/su80 20119

Silva, L., and Sareen, S. (2021). Solar photovoltaic energy infrastructures, land use and sociocultural context in Portugal. Local Environ. 26, 347-363.

Simcock, N., Frankowski, J., and Bouzarovski, S. (2021). Rendered invisible: institutional misrecognition and the reproduction of energy poverty. Geoforum 124, 1-9.

Simcock, N., Jenkins, K., Mattioli, G., Lacey-Barnacle, M., Bouzarovski, S., and Martiskainen, M. (2020). Vulnerability to Fuel and Transport Poverty. CREDS Policy Brief 010. Oxford: Centre for Research into Energy Demand Solutions.

Sovacool, B. K. (2014). What are we doing here? Analyzing fifteen years of energy scholarship and proposing a social science research agenda. Energy Res. Soc. Sci. 1, 1-29. doi: 10.1016/j.erss.2014.02.003

Sovacool, B. K. (2021). Who are the victims of low-carbon transitions? Towards a political ecology of climate change mitigation. Energy Res. Soc. Sci. 73:101916. doi: 10.1016/j.erss.2021.101916

Sovacool, B. K., Axsen, J., and Sorrell, S. (2018). Promoting novelty, rigor, and style in energy social science: towards codes of practice for appropriate methods and research design. Energy Res. Soc. Sci. 45, 12-42. doi: 10.1016/j.erss.2018.07.007

Sovacool, B. K., Burke, M., Baker, L., Kotikalapudi, C. K., and Wlokas, H. (2017). New frontiers and conceptual frameworks for energy justice. Energy Policy 105, 677-691. doi: 10.1016/j.enpol.2017. 03.005

Sovacool, B. K., Lipson, M. M., and Chard, R. (2019a). Temporality, vulnerability, and energy justice in household low carbon innovations. Energy Policy 128, 495-504. doi: 10.1016/j.enpol.2019.01.010

Sovacool, B. K., Martiskainen, M., Hook, A., and Baker, L. (2019b). Decarbonization and its discontents: a critical energy justice perspective on four low-carbon transitions. Clim. Change 155, 581-619. doi: 10.1007/s10584-019-02521-7

Steg, L., Perlaviciute, G., and van der Werff, E. (2015). Understanding the human dimensions of a sustainable energy transition. Front. Psychol. 6, 1-17. doi: 10.3389/fpsyg.2015.00805

Uzzell, D., and Räthzel, N. (2009). Transforming environmental psychology. J. Environ. Psychol. 29, 340-350. doi: 10.1016/j.jenvp.2008.11.005

Vargas Payera, S. (2018). Understanding social acceptance of geothermal energy: case study for Araucanía region, Chile. Geothermics 72, 138-144. doi: 10.1016/j.geothermics.2017.10.014

Velasco-Herrejon, P., and Bauwens, T. (2020). Energy justice from the bottom up: a capability approach to community acceptance of wind energy in Mexico. Energy Res. Soc. Sci. 70:101711. doi: 10.1016/j.erss.2020.101711

Waitt, G., Roggeveen, K., Gordon, R., Butler, K., and Cooper, P. (2016). Tyrannies of thrift: Governmentality and older, low-income people's energy efficiency narratives in the Illawarra, Australia. Energy Policy 90, 37-45. doi: 10.1016/j.enpol.2015.11.033

Walker, G. (2009). Beyond distribution and proximity: exploring the multiple spatialities of environmental justice. Antipode 41, 614-636. doi: 10.1111/j.1467-8330.2009.0 0691.x

Walker, G., Cass, N., Burningham, K., and Barnett, J. (2010a). Renewable energy and sociotechnical change: imagined subjectivities of "the public" and their implications. Environ. Plan. A. 42, 931-947. doi: 10.1068/a41400

Walker, G., Devine-Wright, P., Barnett, J., Burningham, K., Cass, N., DevineWright, H., et al. (2011). "Symmetries, expectations, dynamics and contexts: a framework for understanding public engagement with renewable energy 
projects," in Renewable Energy and the Public: From NIMBY to Participation, ed P. Devine-Wright (London: Routledge), 1-14.

Walker, G., Devine-Wright, P., Hunter, S., High, H., and Evans, B. (2010b). Trust and community: exploring the meanings, contexts and dynamics of community renewable energy. Energy Policy 38, 2655-2663. doi: 10.1016/j.enpol.2009.05.055

Weber, E. U., and Stern, P. C. (2011). Public understanding of climate change in the United States. Am. Psychol. 66, 315-328. doi: 10.1037/a00 23253

Williams, A., Mark, G., and Paul, C. (2014). Neoliberalism, big society, and progressive localism. Environ. Plan. A. 46, 2798-2815. doi: 10.1068/a130119p

Wolsink, M. (2007). Wind power implementation: the nature of public attitudes: equity and fairness instead of "backyard motives." Renew.Sustain. Energy Rev. 11, 1188-1207. doi: 10.1016/j.rser.2005.10.005

Wolsink, M. (2018). Co-production in distributed generation: renewable energy and creating space for fitting infrastructure within landscapes. Landsc. Res. 43, 542-561. doi: 10.1080/01426397.2017.1358360

Wolsink, M. (2020). Framing in renewable energy policies: a glossary. Energies 13:2871. doi: $10.3390 /$ en 13112871

Wrapson, W., and Devine-Wright, P. (2014). "Domesticating" low carbon thermal technologies: Diversity, multiplicity and variability in older person, off grid households. Energy Policy 67, 807-817. doi: 10.1016/j.enpol.2013. 11.078
Yoo, H. K., Nguyen, M.-T., Lamonaca, L., Galanakis, K., and Ackrill, R. (2020) Smart-BEEjS Deliverable D3.2 - Socio-Economic Factors \& Citizens' Practices, Enabling Positive Energy Districts Challenging "Silo Thinking" for Promoting PEDs. Available online at: https://smart-beejs.eu/wp-content/uploads/2021/01/ WP3-Deliverable-D3.2_Silo-thinking.pdf (accessed January 26, 2021).

Conflict of Interest: The authors declare that the research was conducted in the absence of any commercial or financial relationships that could be construed as a potential conflict of interest.

Publisher's Note: All claims expressed in this article are solely those of the authors and do not necessarily represent those of their affiliated organizations, or those of the publisher, the editors and the reviewers. Any product that may be evaluated in this article, or claim that may be made by its manufacturer, is not guaranteed or endorsed by the publisher.

Copyright (๑) 2021 Nguyen and Batel. This is an open-access article distributed under the terms of the Creative Commons Attribution License (CC BY). The use, distribution or reproduction in other forums is permitted, provided the original author(s) and the copyright owner(s) are credited and that the original publication in this journal is cited, in accordance with accepted academic practice. No use, distribution or reproduction is permitted which does not comply with these terms. 